\title{
Molecular detection of Toxoplasma gondii in placentas of women who received therapy during gestation in a toxoplasmosis outbreak
}

\author{
Aline Ludwig ${ }^{1}$, Fagner Fernandes ${ }^{2}$, Renata Rojas Guerra ${ }^{1}$, Camila Minuzzi ${ }^{3}$, Patricia \\ Braunig $^{2}$, Alisson Rodrigues Döhler ${ }^{1}$, Luciane Ramos ${ }^{3}$, Liliane Souto Pacheco ${ }^{1}$, Luis \\ Antonio Sangioni ${ }^{3}$, and Fernanda Silveira Flores Vogel $^{1}$ \\ ${ }^{1} \mathrm{UFSM}$ \\ ${ }^{2}$ Universidade Federal de Santa Maria \\ ${ }^{3}$ Affiliation not available
}

October 30, 2020

\begin{abstract}
Toxoplasmosis is a disease caused by T. gondii, a protozoa which affects humans and animals and is widely distributed worldwide. In humans, there is great concern due to the serious consequences that can occur in the infection of pregnant women and the newborn. The early diagnosis of gestational toxoplasmosis is important for treatment to be carried out in order to prevent vertical transmission or reduce damage. The diagnosis can be made through the detection of antibodies in pregnant women or neonates and PCR of amniotic fluid. Previous studies have also reported PCR of the placenta as a good diagnostic test. Our study evaluated the detection of T. gondii DNA in placenta samples from parturients seen at the University Hospital of Santa Maria, Southern Brazil and treated during the pregnancy. We performed PCR in forty samples and five were positive, representing $12.5 \%$. When correlating the treatment time and the detection of DNA in the placentas, no significant result was found. The prevalence of positive samples was lower than in other studies in the literature. The data reaffirm the importance of carrying out the analysis of the placenta. Key words: Placenta, PCR, toxoplasmosis.
\end{abstract}

\section{INTRODUCTION}

Toxoplasmosis is a zoonotic disease worldwide caused by Toxoplasma gondii, an obligate intracellular protozoan and parasite of humans, birds, rodents and other animals (intermediate hosts) and felids (definitive hosts) (Frenkel J.K., Dubey J.P., 1970). Humans may become infected by ingestion of contaminated food or water, vertical transmission, and more rarely by blood transfusion or organ transplantation of infected persons (Dubey et al., 2012). The infection is often symptom-free or mild, but if it occurs during pregnancy it can have serious consequences for the fetus, like retinocoriditis, cerebral calcifications, hydrocephalus, abortion, neonatal death (Joiner and Dubremetz, 1993). The severity of the clinical manifestation is related to the gestation period. The consequences for the fetus are more severe in early pregnancy (Cook et al., 2000).

The prevalence of human T. gondii infection varies in different parts of the world, and has been reported with rates up to $75 \%$ (Pappas et al., 2009). Specifically in Brazil, in pregnant women, there are studies that indicate prevalence of chronic infection from $42 \%$ to $90 \%$ (T.M. et al., 2011). Screening for T. gondii should be performed with dosage of immunoglobulin $\mathrm{G}$ ( $\operatorname{IgG}$ ) antibodies and immunoglobulin $\mathrm{M}$ (IgM) for toxoplasmosis in all pregnant women, ideally during the first trimester of gestation and in women seronegative, monthly or quarterly (Montoya and Remington, 2008).

There is still disagreement about the real efficiency of the treatment of pregnant women (Syrocot et al., 2007; Robert-Gangneux, 2014). Nevertheless, the recommendation in cases of acute infection detected 
during management specific treatment must be immediately initiated to prevent or attack maternal-fetal transmission (Syrocot et al., 2007).

In 2018, an outbreak of toxoplasmosis occurred in Santa Maria, southern Brazil being considered one of the largest outbreaks ever described, with more than 800 confirmed cases, including 3 fetal deaths, 10 miscarriages and 22 cases of congenital toxoplasmosis (Arquilla et al., 2019). In a study conducted during this outbreak T. gondii was isolated from the placental tissues of patients with acute toxoplasmosis who received specific treatment in the third gestation trimester (Minuzzi et al., 2020). The detection of T. gondii in treated patients is generally low (Wallon et al., 2010). Therefore, the objective of this study was to identify the presence of $T$. gondiiDNA in placenta samples of parturients with a history of toxoplasmosis and who received treatment, treated at the University Hospital of Santa Maria (HUSM), located in Santa Maria.

\section{MATERIALS AND METHODS}

Placenta samples from parturients attended at University Hospital of Santa Maria (HUSM) were sent to Laboratory of Parasitic Diseases of the Federal University of Santa Maria (LADOPAR) to diagnostic. Placental tissue fragments of forty positive women in serological screening (IgM e/or IgG) were collected after delivery. All women received specific therapy during pregnancy that consisted of triple treatment (pyrimethamine + sulfadiazine + folinic acid) or spiramycin. The team from the Center for Epidemiological Surveillance HUSM (NVEH) performed the collection of clinical and therapeutic data from the patients, which were subsequently compared with the results of the molecular analyzes.

The placenta samples were subjected to DNA extraction through the Wizard@ Genomic DNA purification kit (Promega, USA) according to the manufacturer's instructions, with modifications in the lysis step according to previous study (Moré et al., 2011; Bräunig et al., 2016). After RNase addition, the lysis step was carried out at a higher temperature $\left(55^{\circ} \mathrm{C}\right)$ and kept overnight, covering a 16 -h interval. The extracted DNA was kept at $-20^{\circ} \mathrm{C}$ until the Polymerase Chain Reaction was performed.

Toxoplasma gondii DNA PCR was performed using a 529 bp genetic marker that repeats approximately 300 times in the $T$. gondiigenome using the forward primer (Tox4) 5' '-CGCTGCAGGGAGGAAGACGAAAGTTG-'3 and primer reverse (Tox5) 5' 'CGCTGCAGACACAGTGCATCTGGATT-3" (Homan et al., 2000). The reaction was run in a final volume of $25 \mu \mathrm{l}$ mixture containing $2.5 \mu \mathrm{l}$ 10x PCR Buffer with $\mathrm{MgCl} 2,10 \mathrm{mM}$ dNTP, $10 \mathrm{pmol}$ of each primer, 1U JumpStart Taq DNA Polymerase (Sigma Aldrich, USA), 100 ng DNA. Amplification was conducted in a thermal with initial denaturation for $5 \mathrm{~min}$ at $94^{\circ} \mathrm{C}$, followed by 35 cycles of 30 seconds at $95^{\circ} \mathrm{C}, 1 \mathrm{~min}$ at $55^{\circ} \mathrm{C}, 1 \mathrm{~min}$ at $72^{\circ} \mathrm{C}$ and a final extension of $5 \mathrm{~min}$ at $72^{\circ} \mathrm{C}$. Amplification products were visualized in transilluminator after $1.5 \%$ agarose gel electrophoresis using gel red as DNA dye. DNA from T. gondii $\mathrm{RH}$ and ultrapure water were used as positive and negative controls, respectively and all DNA samples were tested in duplicate.

The study was approved by the Research Ethics Committee of UFSM under opinion number 3.923.076 and Presentation Certificate for Ethical Appreciation (CAAE) 28325320.9.0000.5346. We use the exact Fisher test to check if there is an association between those variables and PCR results in the table 4 .

\section{RESULTS}

Forty placenta samples were referred to the LADOPAR for detection of $T$. gondii . The women were originally from Santa Maria and other cities in the central region of Rio Grande do Sul, Brazil all were undergoing treatment and gave birth at the HUSM. Five samples (12.5\%) were positive in PCR for T. gondii. We agroup the results of the tests according to the time of treatment the women received (Table 1). Most women received medication for more than 4 months, indicating that toxoplasmosis was diagnosed in the first or second trimester of pregnancy. We looked for whether there is a correlation between a longer treatment time and less chance of detecting the protozoan in the placenta, but statistical analysis showed no correlation (Table 4). The test's null hypothesis is that each PCR result is independent of the other variable's classification (no association). 
T. gondii DNA was detected in five placenta samples. Clinical information about patients with positive pcr samples is shown in table 2. Table 3 shows the treatment protocols and the result of the PCR.

\section{DISCUSSION}

Toxoplasmosis is disregarded in some countries (Wallon and Peyron, 2018) and considered a neglected parasitary disease by the Centers for Disease Control and Prevention (CDC). There are still many failures and difficulties in diagnosing toxoplasmosis. Soares and Caldeira, 2019 published the report of a case of failure in the diagnosis of gestational toxoplasmosis occurred in Brazil. One pregnant woman had signs indicative of toxoplasmosis, but tests were not performed and was characterized as viral, later the newborn was diagnosed with congenital toxoplasmosis.

For the correct diagnosis of gestational toxoplasmosis, tests for anti-toxoplasma IgM and IgG and also IgG avidity (low or high) avidity test should be performed (Tanimura et al., 2015). Amplification of nucleotide sequences in amniotic fluid by PCR or isolation of amniotic fluid parasites may also be used (Leroy et al., 2006). Besides these, according to Robert-Gangneux and Dardé (2012) parasitological examination of placental tissue is one of the usual biologic tools used to diagnose a congenital Toxoplasma infection at birth, along with the serologic screening of the newborn.

Serological screening of pregnant women for toxoplasmosis is performed in Brazil, but there are no wellestablished guidelines and there are still variations between regions (Lopes-Mori et al., 2011). PCR in amniotic fluid or placenta of seropositive pregnant women is not usual procedure in most medical centers in the country.

In this study, placenta samples from women diagnosed and treated for toxoplasmosis during pregnancy were analyzed using conventional PCR for the detection of T. gondii DNA. All samples were from women treated at the HUSM, located in Santa Maria, Southern Brazil. Forty samples of placental tissue were searched and in five $(12.5 \%)$ of these it was possible to detect protozoan DNA.

Examination of the placenta can often be the only indication that there has been congenital infection, in cases of late infection, lack of prenatal diagnosis or when antibodies are not detected in the neonate $(\mathrm{H}$. Fricker-Hidalgo et al., 1998; Robert-Gangneux et al., 2010; Robert-Gangneux and Dardé, 2012). Among the assays currently used for the biologic diagnosis of Toxoplasma infection in neonates, specific IgM analysis of cord blood and neonatal serum had poor sensitivity (Robert-Gangneux et al., 2010). This emphasizes the relevance of carrying out collection and analysis of the placenta.

Different studies have sought the detection of T. gondii DNA in placental tissues. The detection frequency varies between $6.2 \%$ (Filisetti et al., 2010), 25\% (Hélène Fricker-Hidalgo et al., 2007), $60.9 \%$ (Fricker-Hidalgo et al., 1998), $79.5 \%$ (Sterkers et al., 2012) and 86.7\% (Sardarian et al., 2018). In our study, it was possible to detect T. gondii DNA in $12.5 \%$ of the analyzed samples, which differs from other articles. The lower rate of DNA detection in this study may be associated with sampling, that is, placentas from women who were receiving treatment were analyzed. Treatment can reduce the rate of concentration of the protozoan in the placenta and, consequently, directly influence a lower probability of detection of $T$. gondiiDNA (Hélène Fricker-Hidalgo et al., 2007; Robert-Gangneux et al., 2010). However, Fricker-Hidalgo et al. (2007) detected protozoan DNA in $62.5 \%$ of the placentas of pregnant women who were treated with spiramycin. The lower detection in this study may be associated with the fact that the most of pregnant women were treated with pyrimethamine / sulfadiazine / folinic acid. Sardarian et al (2018) analyzed placentas of pregnant women who did not receive treatment and the detection was $86.7 \%$.

Study by Olariu and colaborators (2019) showed that treating pregnant women contributes to better clinical outcomes in babies. There are still questions about treatment to prevent fetal infection or cure, but it is still the best way to prevent more serious long-term damage (Wilson et al., 2011; Maldonado et al., 2017; Diesel et al., 2019). The detection of protozoa in placental tissues is a good indicator of therapeutic efficiency (Sardarian et al., 2018).

The main accepted treatment for toxoplasmosis is a combination of sulfonamides and pyrimethamine (Pe- 
tersen, 2007). Therapy with an association between sulfadiazine, pyrimethamine and folinic acid is indicated for women with more than 18 weeks of pregnancy, for whom it is suspected or confirmed that they acquired acute infection at or after the 18th week of pregnancy, or a positive amniotic Fluid PCR test result is documented, or an abnormal fetal ultrasonograph is suggestive of congenital toxoplasmosis (Maldonado et al., 2017).

During the first trimester of pregnancy, in case of fetal infection, treatment with spiramycin is indicated (KAYE, 2011). The use of pyrimethamine is not recommended during the first trimester of pregnancy for having a teratogenic effect (Montoya and Remington, 2008; Kaye, 2011). In addition, pyrimethamine can suppress activity of the bone marrow. For these reasons, it is recommended to combine with acid folinic (Montoya and Remington, 2008). Sulfadiazine and pyrimethamine act synergistically in blocking olate synthesis pathway by inhibiting the enzymes dihydropterate synthase and dihydrofolate reductase, which are essential for survival and parasite replication (Anderson, 2005).

Several toxoplasmosis outbreaks have been reported around the world, and especially in South America (Meireles et al., 2015). In 2018 one of the biggest outbreaks ever recorded occurred in Santa Maria (Arquilla et al., 2019). Hundreds of people became ill and symptoms are usually mild, but there were cases of abortion, fetal death and the birth of babies with toxoplasmosis. PCR and placental bioassay was performed and toxoplasma was detected (Minuzzi et al., 2020). This event left the population and the medical community on alert to the importance of prevention, as well as making an early and efficient diagnosis. Serological screening and treatment of pregnant women began to be carried out in Santa Maria. Our study was conducted after this outbreak, in the same city, with women in treatment and we found a low rate of positive placentas. We emphasize that the analysis of the placenta can be a differential in the early diagnosis of toxoplasmosis in newborns and should be considered the incorporation into medical protocols. Robert-Gangneux and collaborators (2010) considered the analysis of the placenta an important tool to confirm the diagnosis of infection in newborns and thus provide early treatment.

Although the statistical analysis of this study did not show a relationship between treatment time and detection of protozoan DNA in the placenta, we found a small percentage of positive samples (12.5\%). Romand et al. (2004) pointed out that early maternal treatment can contribute to reducing the parasitic burden detected in the fetal compartment. A positive placenta result is a parameter of critical importance for the management of neonates with suspected congenital infection (Robert-Gangneux and Dardé, 2012).

\section{CONCLUSION}

Our study evaluated the presence of toxoplasma DNA in placenta samples from pregnant women diagnosed with toxoplasmosis during pregnancy and who received treatment. The analyzes detected toxoplasma DNA in $12.5 \%$ of the tested samples. Examination of the placenta can be an important tool in helping to diagnose congenital infection early.

\section{ACKNOWLEDGEMENTS}

The authors are grateful to the Coordination for the Improvement of Higher Education Personnel (CAPES), Brazil, for the financial support.

\section{CONFLICT OF INTEREST}

I declare that there are no conflicts of interest.

\section{ETHICS STATEMENT}

The authors confirm that the ethical policies of the journal, as noted on the journal's author guidelines page, have been adhered to and the appropriate ethical review committee approval has been received. The project was approved by the Research Ethics Committee of Federal University of Santa Maria under Presentation Certificate for Ethical Appreciation (CAAE) 28325320.9.0000.5346.

\section{REFERENCES}


Anderson, A. C. (2005). Targeting DHFR in parasitic protozoa. Drug Discov. Today 10 , 121-128, doi: 10.1016/S1359-6446(04)03308-2.

Arquilla, B., Bloem, C.,Burguêz, D., Andrioli, G., \& Dal Ponte, S. T. (2019). Outbreak of Toxoplasmosis in the City of Santa Maria, Brazil.J. Infect. Dis. Prev. Med. 07 , 7-9, doi: 10.35248/2329-8731.19.7.191.

Bräunig, P., Portella, L. P., Cezar, A. S., Libardoni, F., Sangioni, L. A., Vogel, F. S. F., \& Gonçalvez, P. B. D. (2016) DNA extraction methods and multiple sampling to improve molecular diagnosis of Sarcocystis spp. in cattle hearts. Parasitol. Res. 115 , 3913-3921, doi: 10.1007/s00436-016-5158-3.

Cook, A. J., Gilbert, R. E., Buffolano, W., Zufferey, J., Petersen, E., Jenum, P. A., Foulon, W., Semprini, A. E., \& Dunn, D. T. (2000). Sources of toxoplasma infection in pregnant women: European multicentre case-control study. European Research Network on Congenital Toxoplasmosis. BMJ 321 , 142-7, doi: $10.1201 / 9781420092370$.

Diesel, A. A., Zachia, S. D. A., Müller, A. L. L., Perez, A. V., Uberti, F. A. D. F., \& Magalhães, J. A. D. A. (2019). Follow-up of Toxoplasmosis during Pregnancy: Ten-Year Experience in a University Hospital in Southern Brazil. Rev. Bras. Ginecol. e Obstet.41 , 539-547, doi: 10.1055/s-0039-1697034.

Dubey, J. P., Lago, E. G., Gennari, S.M., Su, C., \& Jones, J. L. (2012) Toxoplasmosis in Humans and Animals in Brazil: High Prevalence, High Burden of Disease, and Epidemiology. Vol. 139Parasitology .

Filisetti, D., Cocquerelle, V., Pfaff, A., Villard, O., \& Candolfi, E. (2010) Placental testing for Toxoplasma gondii is not useful to diagnose congenital toxoplasmosis. Pediatr. Infect. Dis. J.29 , 665-667, doi: 10.1097/INF.0b013e3181d7a725.

Frenkel J. K., Dubey J. P., \& Miller, N. L. (1970) Toxoplasma gondii in cats: fecal stages identified as coccidian oocysts.Science (80-. ). 167, 893-896.

Fricker-Hidalgo, H., Pelloux, H., Racinet, C., Grefenstette, I., Bost-Bru, C., Goullier-Fleuret, A., \& AmbroiseThomas, P.. (1998). Detection of Toxoplasma gondii in 94 placentae from infected women by polymerase chain reaction, in vivo, and in vitro cultures.Placenta 19, 545-549, doi: 10.1016/S0143-4004(98)91049-9.

Fricker-Hidalgo, H., Brenier-Pinchart, M. P., Schaal, J. P., Equy, V., Bost-Bru, C., \& Pelloux, H. (2007) Value of Toxoplasma gondiidetection in one hundred thirty-three placentas for the diagnosis of congenital toxoplasmosis. Pediatr. Infect. Dis. J. 26 , 845-846, doi: 10.1097/INF.0b013e318123e8d3.

Homan, W. L., Vercammen, M., De Braekeleer, J., \& Verschueren, H. (2000). Identification of a 200- to 300 -fold repetitive 529 bp DNA fragment in Toxoplasma gondii, and its use for diagnostic and quantitative PCR. Int. J. Parasitol. 30 , 69-75, doi: 10.1016/s0020-7519(99)00170-8.

Joiner, K. A., \& Dubremetz, J. F. (1993). Toxoplasma gondii : A protozoan for the nineties. Infect. Immun. 61, 1169-1172, doi: 10.1128/iai.61.4.1169-1172.1993.

Kaye, A. (2011). Toxoplasmosis: Diagnosis, treatment, and prevention in congenitally exposed infants. $J$. Pediatr. Heal. Care 25 , 355-364, doi: 10.1016/j.pedhc.2010.04.008.

Leroy, V., Harambat, J., Perez, P., Rudin, C., Gilbert, R., \& Petersen, E. (2006). Performances of tests involved in screening and diagnosing of acute maternal Toxoplasmosis during pregnancy and congenital infection A systematic review, 1985-2005 Panel 3 : prevention and screening issues Suggested Citation : $1-74$.

Lopes-Mori, F. M. R., Mitsuka-Bregano, R., Capobiango, J. D., Inoue, I. T., Reiche, E. M. V., Morimoto, H. K., Casella, A. M. B., Bittencourt, L. H. F. de B., Freire, R. L., \& Navarro, I. T. (2011). Programs for control of congenital toxoplasmosis. Rev. Assoc. Med. Bras.57 , 594-599, doi: 10.1590/S0104-42302011000500021.

Maldonado, Y. A., Read, J. S., Byington, C. L., Barnett, E. D., Davies, H. D., Edwards, K. M., Lynfield, R., Munoz, F.M., Nolt, D., Nyquist, A.C., Rathore, M.H., Sawyer, M.H., Steinbach, W.J., Tan, T.Q., \& 
Zaoutis, T.E. (2017). Diagnosis, treatment, and prevention of congenital toxoplasmosis in the United States. Pediatrics 139 , doi: 10.1542/peds.2016-3860.

MEIRELES, L. R., EKMAN, C. C. J., de ANDRADE JR, H. F., \& LUNA, E. J. de A. (2015). Human Toxoplasmosis Outbreaks and the Agent Infecting Form. Findings From a Systematic Review. Rev. Inst. Med. Trop. Sao Paulo 57 , 369-376, doi: 10.1590/s0036-46652015000500001.

Minuzzi, C. E., Portella, L. P., Braunig, P., Sangioni, L. A., Ludwig, A., Ramos, L. S., Pacheco, L., Silva, C. R., Pacheco, F. C., Menegolla, I. A., Farinha, L. B., Kist, P. P., Bregano, R. M., Nino, B. D. S. L., Martins, F. D. C., Monica, T. C., Ferreira, F. P., Britto, I., Signori, A., Medici, K. C., Freire, R. L., Garcia, J. L., Navarro, I. T., Difante, C. M., \& Vogel, F. S. F. (2020). Isolation and molecular characterization of Toxoplasma gondii from placental tissues of pregnant women who received toxoplasmosis treatment during an outbreak in southern Brazil. PLoS One 15 , 1-8, doi: 10.1371/journal.pone.0228442.

Montoya, J. G., \& Remington, J. S. (2008). Management of Toxoplasma gondii infection during pregnancy. Clin. Infect. Dis. 47 , 554-566, doi: 10.1086/590149.

More, G., Abrahamovich, P., Jurado, S., Bacigalupe, D., Marin, J. C., Rambeaud, M., Venturini, L., \& Venturini, M. C. (2011). Prevalence of Sarcocystis spp. in Argentinean cattle. Vet. Parasitol.177, 162-165, doi: 10.1016/j.vetpar.2010.11.036.

Pappas, G., Roussos, N., \& Falagas, M. E. (2009). Toxoplasmosis snapshots: Global status of Toxoplasma gondii seroprevalence and implications for pregnancy and congenital toxoplasmosis. Int. J. Parasitol. 39 , 1385-1394, doi: 10.1016/j.ijpara.2009.04.003.

Petersen, E. (2007). Toxoplasmosis. Semin. Fetal Neonatal Med.12, 214-223, DOI: 10.1016/j.siny.2007.01.011.

Robert-Gangneux, F. (2014). It is not only the cat that did it: How to prevent and treat congenital toxoplasmosis. J. Infect.68, doi: 10.1016/j.jinf.2013.09.023.

Robert-Gangneux, F., \& Darde, M. L. (2012). Epidemiology of and diagnostic strategies for toxoplasmosis. Clin. Microbiol. Rev.25 , 264-296, doi: 10.1128/CMR.05013-11.

Robert-Gangneux, F., Dupretz, P., Yvenou, C., Quinio, D., Poulain, P., Guiguen, C., \& Gangneux, J. P. (2010). Clinical relevance of placenta examination for the diagnosis of congenital toxoplasmosis.Pediatr. Infect. Dis. J. 29 , 33-38, doi: 10.1097/INF.0b013e3181b20ed1.

Sardarian, K., Maghsood, A., Farimani, M., Hajiloii, M., Saidijam, M., Rezaeepoor, M., Mahaki, H., \& Zamani, A. (2018). Evaluation of Toxoplasma gondii B1 gene in Placental Tissues of Pregnant Women with Acute Toxoplasmosis. Adv. Biomed. Res. 7 , 119, doi: 10.4103/abr.abr_58_18.

Soares, J. A. S., \& Caldeira, A. P. (2019). Congenital toxoplasmosis: The challenge of early diagnosis of a complex and neglected disease.Rev. Soc. Bras. Med. Trop. 52 , 0-2, doi: 10.1590/0037-8682-0228-2018.

Sterkers, Y., Pratlong, F., Albaba, S., Loubersac, J., Picot, M. C., Pretet, V., Issert, E., Boulot, P., \& Bastien, P. (2012). Novel interpretation of molecular diagnosis of congenital toxoplasmosis according to gestational age at the time of maternal infection. J. Clin. Microbiol. 50 , 3944-3951, doi: 10.1128/JCM.0091812.

Syrocot, T., S. Review, and C. Toxoplasmosis. (2007). Effectiveness of prenatal treatment for congenital toxoplasmosis: a meta-analysis of individual patients' data. Lancet 369 , 115-122, doi: 10.1016/S01406736(07)60072-5.

Pessanha, T. M., de Carvalho, M., Pone, M. V. S., \& Gomes Junior, J. S. (2011). Diagnostic and therapeutic management of toxoplasmosis in pregnancy and the effect in the newborn. Rev. Paul. Pediatr.29, 341-347.

Tanimura, K., Nishikawa, A., Tairaku, S., Shinozaki, N., Deguchi, M., Morizane M., Ebina, Y., Morioka, I., \& Yamada, H. (2015). The IgG avidity value for the prediction of Toxoplasma gondii infection in the 
amniotic fluid. J. Infect. Chemother. 21, 668-671, doi: 10.1016/j.jiac.2015.05.013.

Wallon, M., Franck, J., Thulliez, P., Huissoud, C., Peyron, F., Garcia-Meric, P., \& Kieffer, F. (2010). Accuracy of real-time polymerase chain reaction for Toxoplasma gondii in amniotic fluid. Obstet. Gynecol. 115 , 727-733, doi: 10.1097/AOG.0b013e3181d57b09.

Wallon, M., \& Peyron, F. (2018). Congenital toxoplasmosis: A plea for a neglected disease. Pathogens 7 , 1-9, doi: 10.3390/pathogens7010025.

Wilson, C., Nizet, V., Maldonado, Y., Remington, J., Krupp, M. A., \& Klein, J.. (2011). Infectious Diseases of the Fetus and Newborn Infant.Infect. Dis. Fetus Newborn Infant . Philadelphia: Elsevier.

\section{Hosted file}

Table 1.pdf available at https://authorea.com/users/371593/articles/489869-moleculardetection-of-toxoplasma-gondi-in-placentas-of-women-who-received-therapy-duringgestation-in-a-toxoplasmosis-outbreak

\section{Hosted file}

Table 2.pdf available at https://authorea.com/users/371593/articles/489869-moleculardetection-of-toxoplasma-gondii-in-placentas-of-women-who-received-therapy-duringgestation-in-a-toxoplasmosis-outbreak

\section{Hosted file}

Table 3.pdf available at https://authorea.com/users/371593/articles/489869-moleculardetection-of-toxoplasma-gondi-in-placentas-of-women-who-received-therapy-duringgestation-in-a-toxoplasmosis-outbreak

\section{Hosted file}

Table 4.pdf available at https://authorea.com/users/371593/articles/489869-moleculardetection-of-toxoplasma-gondii-in-placentas-of-women-who-received-therapy-duringgestation-in-a-toxoplasmosis-outbreak 